\title{
A Survey of Declining Palms (Arecaceae) With 16SrIV-D Phytoplasma to Evaluate the Distribution and Host Range in Florida
}

\author{
Brian W. Bahder ${ }^{1,}$, Noemi Soto ${ }^{1}$, Ericka E. Helmick ${ }^{1}$, Kishore K. Dey ${ }^{2}$, Lidia Komondy ${ }^{1}$, Alessandra R. Humphries ${ }^{1}$, De-fen Mou ${ }^{1}$, \\ Richard Bailey $^{3}$, Marina S. Ascunce ${ }^{4}$, Erica M. Goss ${ }^{4}$ \\ ${ }^{1}$ University of Florida, Department of Entomology and Nematology - Fort Lauderdale Research and Education Center, Davie, FL \\ 33314-7719 \\ ${ }^{2}$ Florida Department of Agriculture and Consumer Services, Division of Plant Industry, Gainesville 32614 \\ ${ }^{3}$ Professional Forester, Inc., Plant City, FL 33567-3406 \\ ${ }^{4}$ University of Florida, Department of Plant Pathology and Emerging Pathogens Institute, Gainesville, FL 32611
}

\begin{abstract}
The 16SrIV-D phytoplasma was first identified in Florida in 2006. Since its discovery, it has spread throughout most of the state. It is most prevalent in the central part of Florida, from Hillsborough County on the west coast to St. Lucie County on the east coast. The 16SrIV-D phytoplasma is the causal agent of lethal bronzing disease (LBD), which is also known as Texas Phoenix palm decline (TPPD). It affects a variety of common and economically important ornamental palm species as well as the native and ecologically important species, Sabal palmetto. It has spread into the southern portions of Florida, where the palm species diversity is higher. The aims of this survey were to document the spread of disease in terms of geographic and host range one decade after its introduction into Florida, and to assess the risk that LBD poses to the nursery and

landscaping industries. The survey included samples received from stakeholders throughout the state, covering 18 counties, as well as a systematic sampling of palms at the Fort Lauderdale Research and Education Center (FLREC), where the disease is spreading actively. The findings of this survey resulted in the detection of LBD in eight new counties, including Collier, Hernando, Jefferson, Martin, Miami-Dade, Monroe, Seminole, and St. Johns, and the expansion of LBD into four new host species, Cocos nucifera, Livistona chinensis, Butia capitata, and Carpentaria acuminata. These findings are crucial for stakeholders because they highlight new hosts of 16SrIV-D phytoplasma and the geographic expansion of the disease, indicating that vigilance is needed when surveying declining palms.
\end{abstract}

The 16SrIV-D phytoplasma was first discovered in Hillsborough County, Florida, in 2006, in declining Canary Island Date Palms (Phoenix canariensis Chabaud), Edible Date Palms (P. dactylifera L.), Wild Date Palms (P. sylvestris L.), and Queen Palm (Syagrus romanzoffiana Chamisso) (Harrison et al. 2008). Previously the 16SrIV-D phytoplasma had only been known in Texas, where it was isolated from $P$. canariensis (Harrison et al. 2002). Subsequently, in 2008, the 16SrIV-D phytoplasma was isolated from declining Cabbage Palms (Sabal palmetto Walter) in Florida (Hillsborough and Manatee County) (Harrison et al. 2009). In 2011, the 16SrIV-D phytoplasma was also isolated from a declining Pygmy Date Palm (P. roebelinii O'Brien) in Florida (Hillsborough County) (Jeyaprakash et al. 2011). The most recent new host record for the 16SrIV-D phytoplasma in Florida was from the Bismarck Palm (Bismarckia nobilis Hildebr \& Wendl) in Manatee County (Dey et al. 2018). In addition to Florida and Texas, the only other states within the United States where 16SrIV-D phytoplasma has been detected is Louisiana, where it was detected in declining Chinese Windmill Palms (Trachycarpus fortunei Hook) (Singh and Ferguson 2017). Outside of the United States, the 16SrIV-D has been found only in Mexico in declining Sabal mexicana Martius and Pseudophoenix sargentii Wendl (Vázquez-Euán et al. 2011), Christmas Palm (Adonidia merrillii Beccari) (Lara et al. 2017), and Pritchardia pacifica Seeman \& Wendl (Narváez et al. 2017). Based on published

${ }^{\dagger}$ Corresponding author: B. W. Bahder; bbahder@ufl.edu

Funding: Funding for this project was provided through the Farm Bill cooperative agreement number 8130-0148-CA and the University Florida Emerging Pathogens Institute seed (grant no. 11900000-101-2200-CYFWD).

The author(s) declare no conflict of interest.

Accepted for publication 14 May 2019.

(C) 2019 The American Phytopathological Society records, this resulted in a total of 12 susceptible palm species hosts of the 16SrIV-D phytoplasma, with seven of the susceptible species confirmed in the state of Florida. In contrast, the 16SrIV-A phytoplasma, which is the causal agent of lethal yellowing (LY), is known to affect $>30$ different species of palm in Florida (Bahder and Helmick 2018a), and it was introduced to the southern portion of the state (Corbett 1959), where palm diversity is relatively higher. Many of the host records of LY are because of the introduction of the disease to Fairchild Tropical Botanic Garden (Howard and Collins 1978), which houses $>100$ species of palms, most of which are non-native and tropical in origin and therefore cannot survive north of the subtropical climate of south Florida. It is important to note that the hosts associated with LY were established before the use of molecular techniques. The diagnostics were based on scanning electron microscopy (SEM), which demonstrated the presence of phytoplasma; however, it could not distinguish between groups or subgroups as they are currently known, thereby casting doubts regarding whether all cases of reported hosts of LY were caused by the 16 SrIV-A phytoplasma or other groups. Therefore, there is a need for the systematic study of declining palms in Florida using molecular diagnostics.

The 16SrIV-D phytoplasma is the causal agent of a disease that was initially called Texas Phoenix Palm decline (TPPD) because of its original discovery in Texas in declining $P$. canariensis. However, the disease is currently referred to as lethal bronzing disease (LBD) in Florida (Bahder et al. 2018) and Date Palm lethal decline (DPLD) in Texas (Giesbrecht et al. 2014). The name LBD was proposed because it accurately described symptoms observed in affected host species, in which dying leaves display a bronze coloration that varies in hue among species but is consistently different than the color of naturally senescing leaves of palms (Bahder et al. 2019).

The spread of the16SrIV-D phytoplasma in the urban environment of south Florida was observed in Sa. palmetto and Sy. romanzoffiana at the UF/IFAS Fort Lauderdale Research and Education Center (FLREC); these were infected after the presumed introduction of an infective insect vector (Bahder et al. 2018). This study revealed 
a decline of approximately $50 \%$ of $\mathrm{Sa}$. palmetto and $25 \%$ of $\mathrm{Sy}$. romanzoffiana over the course of a period of approximately 3 years. After the termination of this study, further infections were observed in these $S a$. palmetto and $P$. roebelinii. At the time, the outbreak of LBD at FLREC was the southernmost recorded instance of the 16SrIV-D phytoplasma in Florida (Harrison and Elliott 2016). The FLREC is an ideal location for evaluating the potential of the 16SrIV-D to infect previously unknown hosts because there is a higher diversity of palms at the research station than in surrounding areas (T. Broschat, personal communication). Evaluating which palm species are susceptible in a single location can help determine the true host range of the phytoplasma. In parallel, studying the host and geographic distributions of the pathogen throughout the state improves our understanding of the true economic impact of the pathogen in Florida.

The primary objective of this survey was to expand our knowledge of the host range and distribution of the 16SrIV-D phytoplasma in Florida by surveying palm species at the FLREC and samples from declining palms throughout the state taken by stakeholders (landscaping and nursery personnel). The results of this study provide valuable data to stakeholders by elucidating the increasing geographical and host range of the 16SrIV-D phytoplasma in Florida and by providing further impetus for sampling new potential hosts.

\section{Materials and Methods}

Sample collection and processing. All samples taken from palms at FLREC $(26.084006,80.237431)$ consisted of trunk tissue that was obtained according to the protocol outlined by Bahder and Helmick (2018b). Samples were obtained between 1 July, 2016 and 20 March, 2019; they were collected from palms that displayed typical symptoms of premature fruit drop/inflorescence necrosis, discolored older leaves, and/or spear leaf collapse. In addition to symptomatic palms, adjacent palms of the same species that were asymptomatic were also included in this study. Furthermore, other palm species that did not display symptoms but were adjacent to symptomatic palms were also sampled. All samples obtained from stakeholders were collected from trunk tissues according to the protocols outlined by Bahder and Helmick (2018b). These samples were collected during the same time period when samples were collected for the survey at FLREC. All samples were processed by macerating $1 \mathrm{~g}$ of tissue in guanidine buffer (guanidine thiocyanate, $4 \mathrm{M}$ and $3 \mathrm{M}$; sodium acetate, $0.2 \mathrm{M}$ and $0.5 \mathrm{M}$; EDTA, 0.25M; PVP-40, $0.0006 \mathrm{M}$ ) in a BioReba extraction bag using the HOMEX6 tissue homogenizer. Then, lysate was extracted using the Plant Mini Kit (Qiagen) as per the manufacturer's instructions. The excess plant tissue was stored at $-80^{\circ} \mathrm{C}$.

Screening of palms by quantitative PCR and melt curve analysis. Eluate obtained from the extraction protocol was diluted to $25 \mu \mathrm{l}$ when necessary before screening was performed using quantitative PCR (qPCR). All samples were screened using the qPCR parameters, primers, and probe presented by Córdova et al. (2014). After this TaqMan assay, samples that tested positive were screened by a second qPCR assay according to the methods of Bahder et al. (2017) to determine if they were infected with the 16SrIV-A or 16SrIV-D phytoplasma. A standard PCR with primers LY16-LSF/LY16-LSR (Córdova et al. 2014) was used for amplification of the gDNA from sample Spa-12, which had tested positive for LBD. Each PCR contained 5x GoTaq Flexi Buffer, $25 \mathrm{mM}$ of $\mathrm{MgCl}_{2}, 10 \mathrm{mM}$ of dNTP, $10 \mathrm{mM}$ of each primer, $10 \%$ of PVP-40, $2.5 \mathrm{U}$ of GoTaq Flexi DNA polymerase, and sterile $\mathrm{dH}_{2} \mathrm{O}$ to a final volume of $25 \mu$. Thermocycling parameters were as follows: $94^{\circ} \mathrm{C}$ for 1 min during the initial denaturation, followed by 35 cycles of $94^{\circ} \mathrm{C}$ for $30 \mathrm{~s}, 60^{\circ} \mathrm{C}$ for $30 \mathrm{~s}, 72^{\circ} \mathrm{C}$ for $30 \mathrm{~s}$, and a final extension of $72^{\circ} \mathrm{C}$ for $5 \mathrm{~min}$. Three $\mu \mathrm{l}$ of each product was electrophoresed on a $1.5 \%$ agarose gel stained with GelRed nucleic acid gel stain (Biotium, Hayward, CA) and visualized using ultraviolet transillumination.

PCR products were cloned using a TOPO TA cloning kit into vector pCR 2.1-TOPO (Invitrogen) according to the manufacturer's protocol. The cloning constructs were transformed into chemically competent $E$. coli cells using the TOPO One Shot and plated on
LB plates containing $50 \mu \mathrm{g} / \mathrm{ml}$ of kanamycin. Plates were incubated overnight at $37^{\circ} \mathrm{C}$, and transformed colonies were chosen for the colony PCR using primers LY16-LSF/LY16-LSR (Córdova et al. 2014) to verify that they contained the correct insert. Clones with an insert of the correct size were incubated on a shaker overnight in $20 \mathrm{ml}$ of LB broth with $50 \mu \mathrm{g} / \mathrm{ml}$ of kanamycin. Plasmids were extracted using a QIAprep Spin Miniprep Kit (Qiagen) per the manufacturer's protocol. Plasmid concentrations were quantified using either a NanoDrop spectrophotometer (ThermoFisher Scientific, Waltham, MA) or a Qubit 2.0 Fluorometer (ThermoFisher) using the Qubit dsDNA BR Assay Kit (Invitrogen). Ten-fold serial dilutions were created $\left(10^{8}\right.$ to $\left.10^{3}\right)$ for use as standards in the qPCR assays that were used to generate the standard curve and quantity estimation for all samples.

All qPCR assays were performed using QuantStudio real-time PCR software v1.3 (Life Technologies, Inc.). All qPCR assays were performed in triplicate for each specimen. When a single palm of a species was positive, the average copy number and standard error were calculated based on the replication of the same sample, whereas species with multiple specimens that tested positive were presented as the average of the replications of each specimen followed by the average of all specimens.

Nested PCR reactions and sequencing. For palm species that were not previously known hosts of the 16SrIV-D phytoplasmas, sequence data were obtained by amplifying a portion of the $16 \mathrm{~S}$ rDNA

Table 1. Phytoplasma isolates used for the construction of the maximum likelihood tree to establish the relationship of isolates from the new palm host identified in Florida

\begin{tabular}{|c|c|c|}
\hline $\begin{array}{l}16 \mathrm{Sr} \\
\text { Classification }\end{array}$ & Disease & $\begin{array}{c}\text { GenBank } \\
\text { Accession No. }\end{array}$ \\
\hline $\mathrm{I}-\mathrm{A}$ & Aster yellows witches' broom & NC_007716 \\
\hline II-A & Peanut witches' broom & L33765 \\
\hline III-A & Peach X-disease & JQ044392 \\
\hline IV-A & Lethal yellowing & AF498309.1 \\
\hline IV-B & Yucatan coconut lethal decline & U18753.2 \\
\hline IV-C & Tanzanian coconut lethal decline & X80117.1 \\
\hline IV-D & Lethal Bronzing & MG993140.1 \\
\hline IV-E & Dominican Republic coconut lethal decline & DQ631639.1 \\
\hline IV-F & Washingtonia Robusta lethal decline & EU241512.1 \\
\hline $\mathrm{V}-\mathrm{A}$ & Elm yellows & AY197655 \\
\hline VI-A & Clover proliferation & AY390261 \\
\hline VII-A & Ash yellows & AF092209 \\
\hline VIII-A & Loofah Witches' broom & AF086621 \\
\hline IX-A & Pigeon pea witches' broom & AF248957 \\
\hline $\mathrm{X}-\mathrm{A}$ & Apple proliferation & AJ542541 \\
\hline XI-A & Rice yellow dwarf & $\mathrm{AB} 052873$ \\
\hline XII-A & Stolbur & AF248959 \\
\hline XIII-A & Mexican periwinkle virescence & AF248960 \\
\hline XIV-A & Bermuda white leaf & AJ550984 \\
\hline XV-A & Hibiscus witches' broom & AF147708 \\
\hline XVI-A & Sugarcane yellow leaf syndrome & AY725228 \\
\hline XVII-A & Papaya bunchy top & AY725234 \\
\hline XVIII-A & American potato purple top wilt & DQ174122 \\
\hline XIX-A & Chestnut witches' broom & AB054986 \\
\hline $\mathrm{XX}-\mathrm{A}$ & Rhamnus witches' broom & AJ583009 \\
\hline XXI-A & Pine phytoplasma & AJ310849 \\
\hline XXII-A & Lethal yellow disease Mozambique & KF751387 \\
\hline XXIII-A & Buckland valley grapevine yellows & AY083605 \\
\hline XXIV-A & Sorghum bunchy shoot & AF509322 \\
\hline XXV-A & Weeping tea witches' broom & AF521672 \\
\hline XXVI-A & Sugarcane phytoplasma D3T1 & AJ539179 \\
\hline XXVII-A & Sugarcane phytoplasma D3T2 & AJ539180 \\
\hline XXVIII-A & Derbid phytoplasma & AY744945 \\
\hline XXIX-A & Cassia witches' broom & EF666051 \\
\hline XXX-A & Salt Cedars witches' broom & FJ432664 \\
\hline XXXI-A & Soybean stunt & HQ225630 \\
\hline XXXII-A & Malaysian p. virescence & EU371934 \\
\hline XXXIII-A & Allocasuarina phytoplasma & AY135523 \\
\hline
\end{tabular}


using standard and nested PCR protocols, as outlined by Bahder et al. (2018). Amplified products from the nested PCR reaction were purified using the ExoSAP-I PCR product cleanup reagent (ThermoFisher Scientific) according to the manufacturer's protocol. The cleaned PCR products were sent to Eurofins Diagnostics for sequencing. The resulting sequences were assembled, visually inspected, and corrected for sequencing errors using DNA Baser v. 4.36 (Heracle Biosoft); then, they were aligned using MEGA7 (Kumar et al. 2016). All sequences were identified as 16 S rDNA phytoplasma sequences via nucleotide BLAST on the NCBI website (https://blast. ncbi.nlm.nih.gov).

Sequence analysis and subgroup determination. To establish group and subgroup classifications for phytoplasmas isolated from new host species, the obtained sequences were aligned with $16 \mathrm{~S}$ sequences from isolates of the A subgroup from each known $16 \mathrm{Sr}$ group known to date and all subgroups from the 16rIV group (Table 1). Subgroup A was selected because, in general, A subgroups

Table 2. Palm species sampled and tested by quantitative PCR at the Fort Lauderdale Research and Education Center for the presence of the 16SrIV-D phytoplasma

\begin{tabular}{|c|c|c|c|c|c|}
\hline Species & $\begin{array}{c}\text { No. } \\
\text { Infected }\end{array}$ & $\begin{array}{c}\text { No. } \\
\text { Tested }\end{array}$ & Avg. $\mathbf{C t}^{\mathrm{a}}$ & Avg. Qty. ${ }^{b}$ & Avg. $\operatorname{Tm}^{\mathrm{c}}$ \\
\hline Adonidia merrillii & 1 & 5 & $25.4 \pm 0.1$ & $30,199 \pm 433$ & $80.03 \pm 0.0$ \\
\hline $\begin{array}{r}\text { Carpentaria } \\
\text { acuminata }\end{array}$ & 1 & 4 & $24.2 \pm 0.1$ & $156,777 \pm 100$ & $80.03 \pm 0.0$ \\
\hline Cocos nucifera & 3 & 100 & $28.1 \pm 0.2$ & $9,222 \pm 678$ & $80.03 \pm 0.0$ \\
\hline Phoenix reclinata & 0 & 5 & $\mathrm{No} C t$ & 0 & $60.1 \pm 0.0$ \\
\hline $\begin{array}{l}\text { Phoenix } \\
\quad \text { roebelinii }\end{array}$ & 2 & 11 & $23.1 \pm 0.2$ & $221,334 \pm 2,344$ & $80.01 \pm 0.0$ \\
\hline Roystonea regia & 0 & 10 & $\mathrm{No} C t$ & 0 & $60.2 \pm 0.0$ \\
\hline Sabal etonia & 0 & 1 & No $\mathrm{Ct}$ & 0 & $62.3 \pm 0.0$ \\
\hline Sabal palmetto & 10 & 21 & $20.9 \pm 0.4$ & $856,799 \pm 20,998$ & $80.01 \pm 0.0$ \\
\hline $\begin{array}{l}\text { Sabal } \\
\quad \text { mauritiioformis }\end{array}$ & 0 & 5 & No Ct & 0 & $\mathrm{~N} / \mathrm{A}^{\mathrm{d}}$ \\
\hline Serenoa repens & 0 & 20 & $\mathrm{No} C t$ & 0 & N/A \\
\hline $\begin{array}{l}\text { Syagrus } \\
\quad \text { romanzoffiana }\end{array}$ & 2 & 2 & $25.4 \pm 0.4$ & $31,201 \pm 3,566$ & $80.01 \pm 0.0$ \\
\hline $\begin{array}{l}\text { Wodeytia } \\
\text { bifurcata }\end{array}$ & 0 & 10 & No $\mathrm{Ct}$ & 0 & N/A \\
\hline $\begin{array}{l}\text { (+) Control } \\
(16 \text { SrIV-D) }\end{array}$ & N/A & N/A & $22.3 \pm 0.1$ & $324,000 \pm 889$ & $80.03 \pm 0.0$ \\
\hline $\begin{array}{l}\text { (+) Control } \\
\text { (16SrIV-A) }\end{array}$ & N/A & N/A & $24.6 \pm 0.1$ & $115,444 \pm 431$ & $80.54 \pm 0.0$ \\
\hline Healthy control & N/A & N/A & No $\mathrm{Ct}$ & 0 & $60.1 \pm 0.0$ \\
\hline Water control & N/A & N/A & No $\mathrm{Ct}$ & 0 & $60.2 \pm 0.0$ \\
\hline
\end{tabular}

${ }^{\mathrm{a}} \mathrm{Ct}=$ cycle threshold for measuring dye florescence relative to reference dye.

${ }^{\mathrm{b}} \mathrm{Qty} .=$ estimated copy number per microliter.

${ }^{\mathrm{c}} \mathrm{Tm}=$ melting temperature of the amplicon in ${ }^{\circ} \mathrm{C}$.

d N/A = Not applicable are more common and generally more representative of the disease with which they are associated. Additionally, an isolate of Acholeplasma palmae (accession no. NR_029152.1) was included as an outgroup in the analysis. To establish subgroup classifications of the isolates obtained in this study, sequences were subjected to the construction of a maximum likelihood tree with 1,000 replicates.

\section{Results}

qPCR screening of palms. From 1 July 2016 to 20 March, 2019, 189 palm samples that comprised 11 different species were taken at FLREC (Table 2). Of the species sampled at FLREC, Sa. palmetto, Sy. romanzoffiana, $P$. roebelinii, and Adonidia merrillii were previously described host species of the 16SrIV-D phytoplasma, whereas Carpentaria acuminata Wendland \& Drude, Phoenix reclinata, Sa. mauritiiformis, Serenoa repens, Sa. etonia, Cocos nucifera L., Roystonea regia, and Wodyetia bifurcata were not known hosts of the 16SrIV-D. Symptoms were observed in 14 Sa. palmetto (Fig. 1), one Sy. romanzoffiana (Fig. 1), two P. roebelinii (Fig. 1), two A. merrillii (Fig. 1), one Carpentaria acuminata (Fig. 1), and two Cocos nucifera (Figs. 2 and 3). All specimens that exhibited symptoms tested positive by the TaqMan qPCR assay (Table 2) and yielded a melting temperature (Tm) signature that matched positive controls for the 16SrIV-D phytoplasma in the melt curve analysis (Table 2). In addition to these samples, a single Cocos nucifera that did not exhibit symptoms at the time of

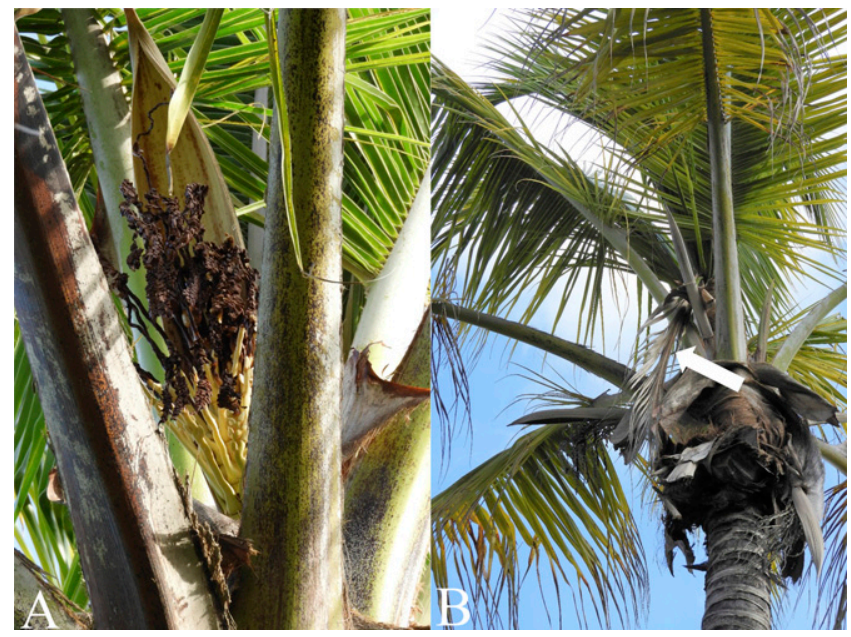

Fig. 2. A, Necrotic inflorescence and B, collapsed spear leaf from Cocos nucifera infected with the 16SrIV-D phytoplasma.

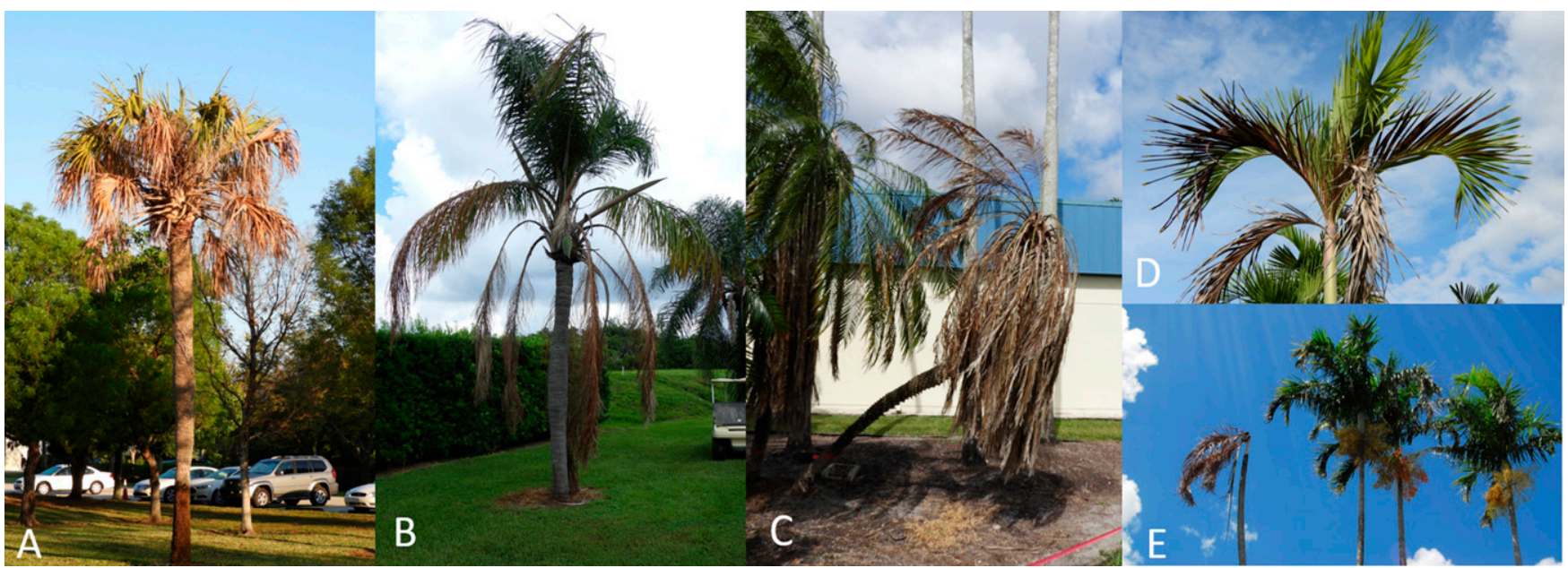

Fig. 1. A, Symptomatic Sabal palmetto, B, Syagrus romanzoffiana, C, Phoenix roebelinii, D, Adonidia merrillii, and E, Carpentaria acuminata infected with the 16SrlV-D phytoplasma at the Fort Lauderdale Research and Education Center. 
sampling tested positive for the 16SrIV-D phytoplasma by qPCR and was confirmed by the melt curve analysis. All other palms sampled that did not exhibit symptoms tested negative for phytoplasma. Asymptomatic palms included Phoenix reclinata Jacquin, Roystonea regia Kunth, Sabal etonia Swingle, Sabal mauritiioformis Karsten, Serenoa repens Bartram, and Wodeytia bifurcata Irvine.

From 1 July, 2016 to 20 March, 2019, a total of 302 samples were received from throughout Florida (Table 3 ). Samples were submitted by landscape/nursery personnel as well as county extension agents and private homeowners. Of the samples received, the majority were taken from $P$. sylvestris (61.3\% of total samples), with $56.2 \%$ testing positive (Table 3 ). The next two most abundant species sampled were $P$. dactylifera (9.6\% of total samples) and $P$. canariensis ( $8.6 \%$ of total samples), with 51.7 and $34.6 \%$, respectively, testing positive (Table 3). Eleven samples of Sa. palmetto and seven samples of Sy. romanzoffiana were received, with 54.5 and $57.1 \%$ testing positive for phytoplasma, respectively (Table 3 ). Other species that tested positive but that are not included in Table 3 are Butia capitata Martius (two of five samples tested positive) (Fig. 4) and Livistona chinensis Jacquin (one of five samples tested positive) (Fig. 5). Other palm samples that were submitted but tested negative (no cycle threshold) were Cocos nucifera (nine samples), Bismarckia nobilis (three samples), Washingtonia robusta Wendland (seven samples), Adonidia merrillii (two samples), Wodyetia bifurcata (seven samples), Livistona nitida Rodd (one sample), and Coccothrinax saxicola León (one sample). All samples that tested positive for phytoplasma yielded a Tm product that matched the Tm product for the 16SrIV-D positive control (Table 4). Of the palms included in this sample, Butia capitata, Carpentaria acuminata, Cocos nucifera, and L. chinensis represented new host records for the 16SrIV-D phytoplasma; they were sequenced for further analysis and confirmation. Although a known host of the 16SrIV-D phytoplasma in
Table 3. Total samples of common palms surveyed by stakeholders throughout the state of Florida and those that tested positive

\begin{tabular}{|c|c|c|c|c|c|}
\hline County ${ }^{a}$ & $\begin{array}{c}P . \\
\text { sylvestris }\end{array}$ & $\begin{array}{c}P . \\
\text { dactylifera }\end{array}$ & $\begin{array}{c}P . \\
\text { canariensis }\end{array}$ & $\begin{array}{c}\text { Sa. } \\
\text { palmetto }\end{array}$ & $\begin{array}{c}\text { Sy. } \\
\text { romanzoffiana }\end{array}$ \\
\hline Alachua & $1 / 1$ & $\mathrm{~N} / \mathrm{A}^{\mathrm{b}}$ & N/A & N/A & N/A \\
\hline Bay & $0 / 7$ & N/A & N/A & N/A & N/A \\
\hline Broward & $0 / 1$ & N/A & N/A & $0 / 1$ & N/A \\
\hline Charlotte & $0 / 1$ & N/A & $0 / 1$ & N/A & $0 / 1$ \\
\hline Collier* & $6 / 8$ & $0 / 1$ & N/A & N/A & N/A \\
\hline Duval & $2 / 2$ & N/A & N/A & N/A & N/A \\
\hline Gadsden & $0 / 1$ & N/A & N/A & N/A & N/A \\
\hline Hardee & $4 / 4$ & N/A & N/A & N/A & N/A \\
\hline Hernando* & $1 / 1$ & N/A & N/A & N/A & N/A \\
\hline Highlands & $4 / 4$ & N/A & N/A & N/A & N/A \\
\hline Hillsborough & $4 / 6$ & $5 / 7$ & $1 / 1$ & $4 / 6$ & $1 / 2$ \\
\hline Indian River & $21 / 31$ & $2 / 2$ & $0 / 1$ & N/A & N/A \\
\hline Jefferson* & N/A & $1 / 1$ & N/A & N/A & N/A \\
\hline Lake & $13 / 13$ & N/A & $0 / 1$ & N/A & N/A \\
\hline Lee & $2 / 14$ & N/A & N/A & N/A & N/A \\
\hline Manatee & $3 / 3$ & $7 / 11$ & $0 / 1$ & N/A & N/A \\
\hline Martin* & $1 / 1$ & N/A & $0 / 1$ & N/A & N/A \\
\hline Miami-Dade* & $3 / 6$ & $0 / 3$ & $0 / 4$ & N/A & N/A \\
\hline Monroe* & $2 / 3$ & N/A & $0 / 2$ & N/A & N/A \\
\hline Orange & $7 / 17$ & $0 / 3$ & $4 / 5$ & $0 / 1$ & $1 / 1$ \\
\hline Palm Beach & $2 / 12$ & $0 / 1$ & $1 / 1$ & $1 / 2$ & N/A \\
\hline Polk & $8 / 8$ & N/A & N/A & N/A & N/A \\
\hline Sarasota & $7 / 8$ & N/A & $2 / 4$ & N/A & $0 / 1$ \\
\hline Seminole* & $1 / 7$ & N/A & N/A & N/A & N/A \\
\hline St. Johns* & $6 / 20$ & N/A & N/A & N/A & N/A \\
\hline St. Lucie & $5 / 5$ & N/A & $1 / 3$ & $0 / 1$ & $1 / 1$ \\
\hline Sumter & $2 / 2$ & N/A & $0 / 1$ & $1 / 1$ & N/A \\
\hline Total & $104 / 185$ & $15 / 29$ & $9 / 26$ & $6 / 11$ & $4 / 7$ \\
\hline
\end{tabular}

a Asterisks indicate a new county record

${ }^{\mathrm{b}} \mathrm{N} / \mathrm{A}=$ Not available.

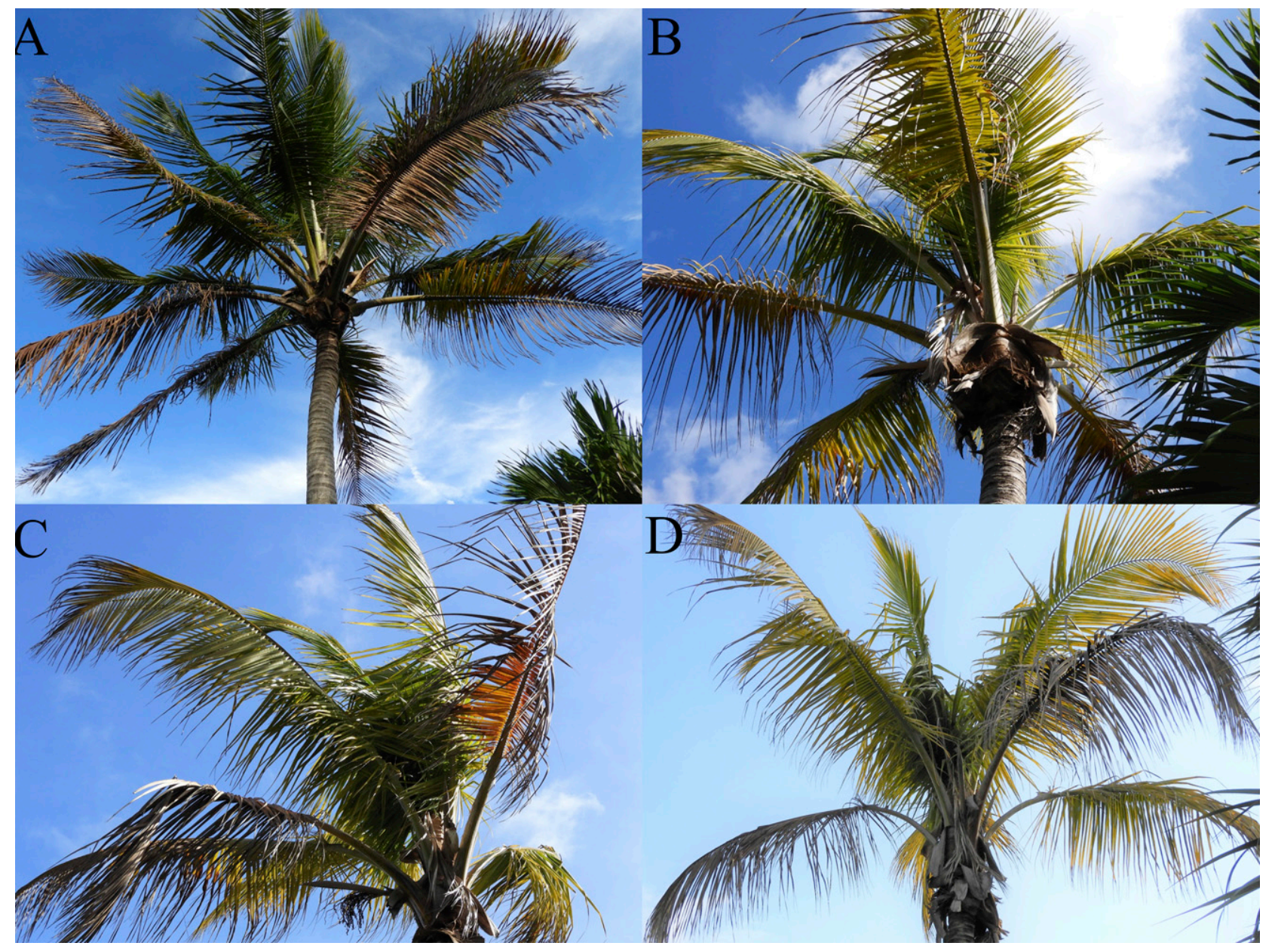

Fig. 3. Symptom progression of lethal bronzing disease in Cocos nucifera Cnu-3200: A, September 2018, B, November 2018, C, January 2019 , D, February 2019. 
Mexico, the isolate from Adonidia merrillii was sequenced because this is the first known case of this species being affected in the United States.

DNA sequence analysis. The $16 \mathrm{~S}$ sequences obtained for the isolates from Adonidia merrillii, Butia capitata (GenBank accession no. MK421966), Carpentaria acuminata (GenBank accession no. MH577010), Cocos nucifera (GenBank accession no. MK421150, MK421151, MK421152), and Livistona chinensis were placed within the 16SrIV phytoplasmas based on the maximum likelihood analysis (Fig. 6). Within this group, they demonstrated $>99 \%$ identity with the 16SrIV-D subgroup, confirming that isolates obtained from these hosts were the 16SrIV-D phytoplasma (Fig. 6).

\section{Discussion}

This survey expanded the known palm hosts of the $16 \mathrm{Sr} 1 \mathrm{~V}$ phytoplasma from 12 to 16 . The new susceptible host species are the Pindo palm (Butia capitata), Carpentaria palm (Carpentaria acuminata), Coconut palm (Cocos nucifera), and Chinese fan palm (Livistona
Table 4. Quantitative PCR and melt curve results for all samples tested on behalf of stakeholders for verification of phytoplasma identity

\begin{tabular}{lrcccc}
\hline Species & N & Avg. Ct $^{\mathbf{a}}$ & Avg. Qty $^{\mathbf{b}}$ & Avg. Tm $^{\mathbf{c}}$ & Tm Range \\
\hline B. capitata & 2 & $20.3 \pm 0.2$ & $921,710 \pm 602$ & $80.3 \pm 0.0$ & N/A $^{\mathrm{d}}$ \\
L. chinensis & 1 & $27.9 \pm 0.0$ & $6,333 \pm 200$ & $80.0 \pm 0.0$ & N/A \\
P. canariensis & 9 & $21.1 \pm 3.1$ & $309,277 \pm 9,001$ & $80.1 \pm 0.3$ & $79.4-80.4$ \\
P. dactylifera & 15 & $24.1 \pm 5.6$ & $64,435 \pm 2,332$ & $80.1 \pm 0.1$ & $79.4-80.1$ \\
P. sylvestris & 104 & $22.5 \pm 9.2$ & $180,430 \pm 3,444$ & $80.1 \pm 0.3$ & $79.4-80.4$ \\
Sa. palmetto & 6 & $22.0 \pm 6.7$ & $204,271 \pm 8,445$ & $80.2 \pm 0.0$ & $80.1-80.3$ \\
Sy. romanzoffiana & 4 & $23.5 \pm 5.4$ & $100,508 \pm 3,499$ & $80.3 \pm 0.2$ & $80.1-80.3$ \\
IV-D (+) control & N/A & $23.4 \pm 0.2$ & $117,428 \pm 1,222$ & $80.1 \pm 0.3$ & $80.0-80.4$ \\
IV-A (+) control & N/A & $25.1 \pm 0.1$ & $56,777 \pm 677$ & $80.8 \pm 0.1$ & $80.6-80.9$ \\
(-) water control & N/A & No Ct & 0 & $60.1 \pm 0.1$ & $58.7-64.9$ \\
(-) healthy control & N/A & No Ct & 0 & $65.4 \pm 0.1$ & $61.1-70.2$ \\
\hline
\end{tabular}

${ }^{a} \mathrm{Ct}=$ cycle threshold for measuring dye florescence relative to reference dye. ${ }^{\mathrm{b}}$ Qty. = estimated copy number per microliter.

${ }^{\mathrm{c}} \mathrm{Tm}=$ melting temperature of the amplicon in ${ }^{\circ} \mathrm{C}$

${ }^{\mathrm{d}} \mathrm{N} / \mathrm{A}=$ Not available.

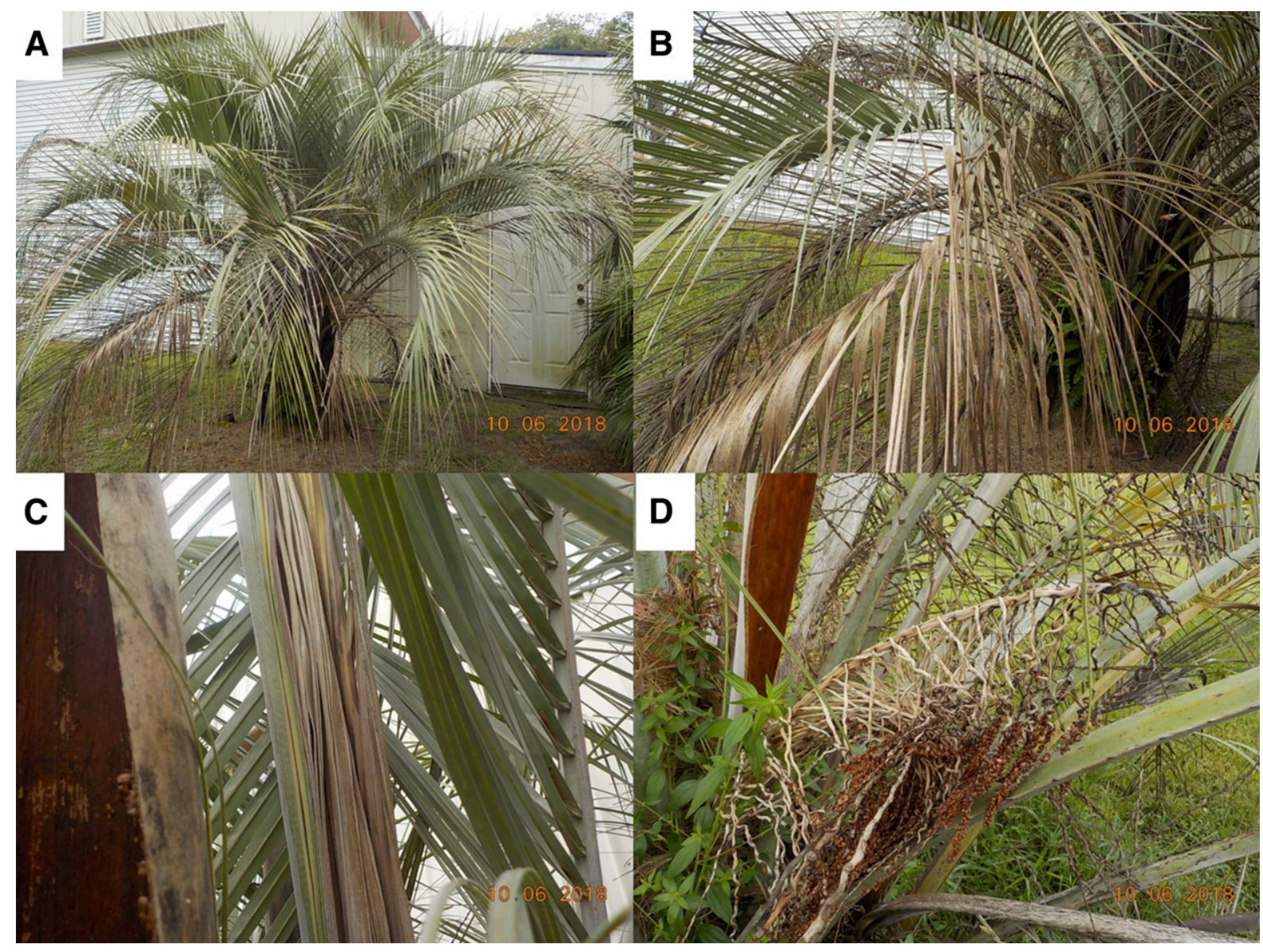

Fig. 4. A, Symptomatic Butia capitata with a close-up of symptomatic, B, bronzed leaves, C, collapsed spear leaf, and D, necrotic inflorescence.

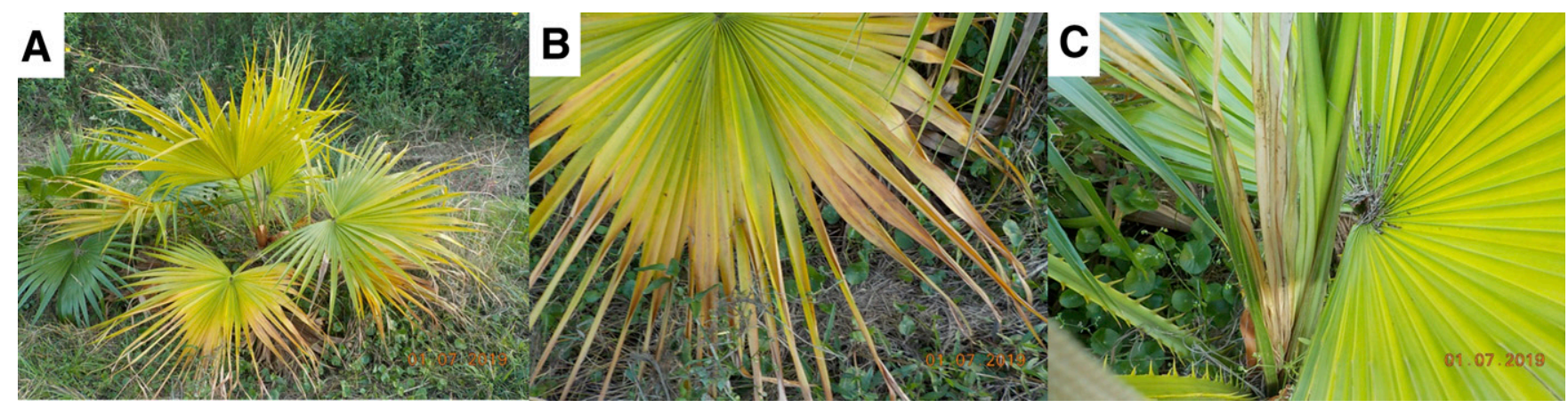

Fig. 5. A, Symptomatic Livistona chinensis with a close-up of symptomatic, B, bronzing leaf, and C, dying spear leaf. 
chinensis). All of these species are common ornamental palms found throughout the southern and coastal central regions of Florida. The knowledge of new palm hosts susceptible to the 16SrIV-D phytoplasma is essential from a management perspective because it allows stakeholders to perform more inclusive sampling of declining palms. Interestingly, the titers measured in C. nucifera and L. chinensis were substantially lower than those of the other hosts documented. This difference could be attributable to sampling error; however, it could also be related to phloem density variations among species. Quantifying the vascular tissue densities among the species presented herein is beyond the scope of the study; however, the variation in phloem density among palm species is well-documented (Rich 1987). This could influence detectable levels of phytoplasma in infected palms; those with the least vascular tissue yielded lower titers, and palms

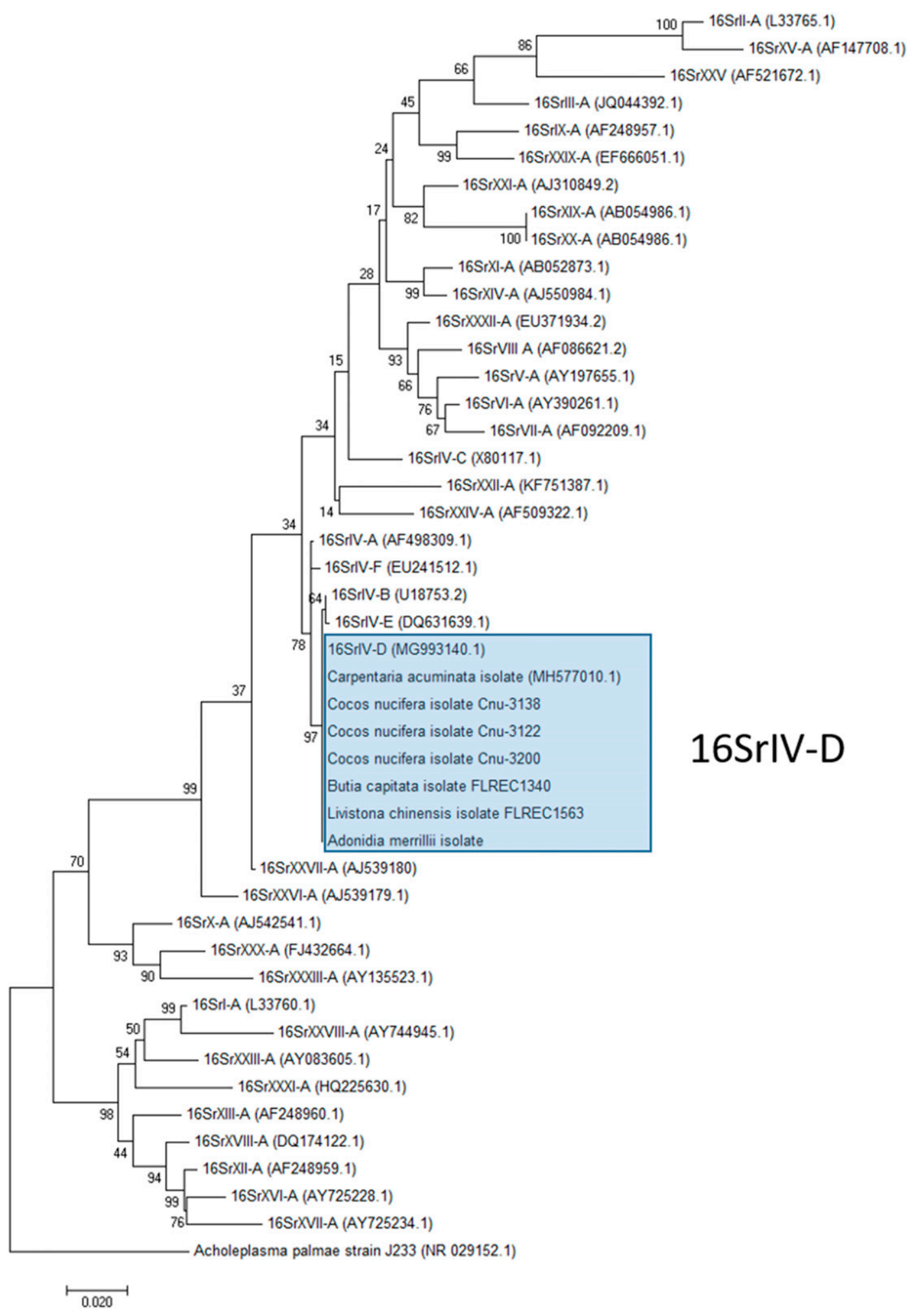

Fig. 6. Maximum likelihood tree generated from the $16 \mathrm{~S}$ gene sequences for all known subgroups of the $16 \mathrm{SrlV}$ phytoplasmas and the A subgroup from all known phytoplasma taxonomic $16 \mathrm{Sr}$ groups with Acholeplasma palmae as an outgroup. Values on branches indicate bootstrap support based on 1,000 samples. Sequences from new hosts Butia capitata, Cocos nucifera, Livistona chinensis, and Carpentaria acuminata are identical to the 16SrIV-D reference sequence. 


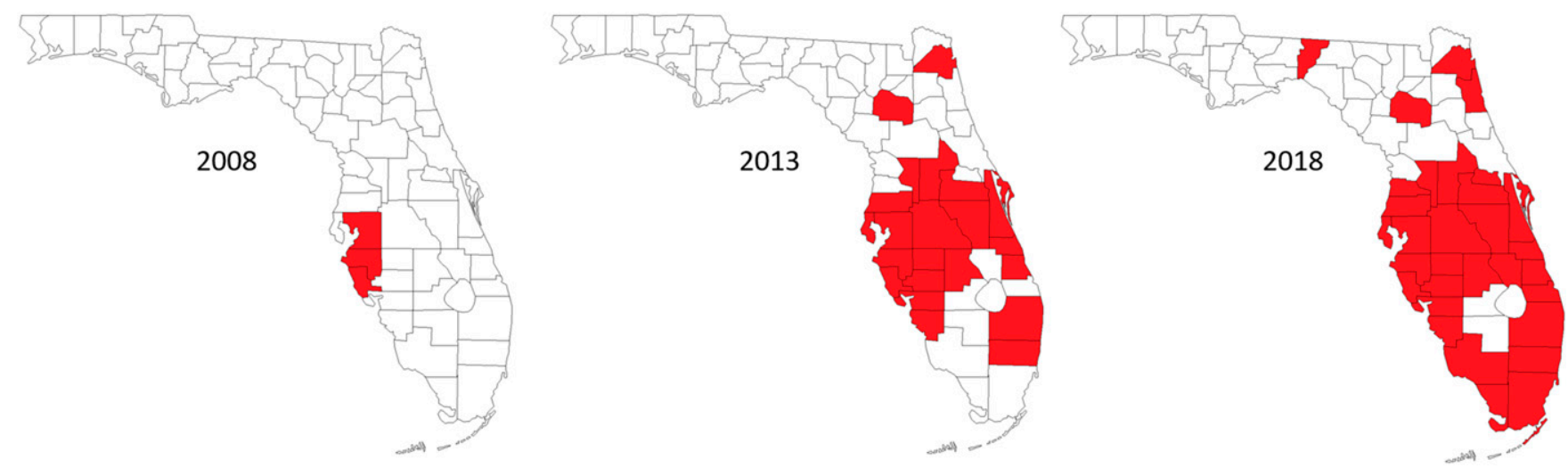

Fig. 7. Distribution of the 16 SrIV-D phytoplasma in Florida by county at approximately the time of discovery in 2008,5 years after discovery in approximately 2013 , and one decade after discovery in approximately late 2018.

with greater amounts of vascular bundles could yield higher titers. An additional explanation is that because these rare host species are not well-categorized, the titers presented in this study are not accurate or representative of the true titers present if additional specimens could be analyzed.

Although the majority of samples received belonged to the genus Phoenix, it is unclear if this was because of the higher susceptibility of the genus or sampling bias. The bias in sampling might have been caused by the difference in values among the palms. Phoenix palms are highly prized; therefore, the stakeholders might have a tendency to sample Phoenix palms more often than Sabal palmetto and Syagrus romanzoffiana, which are considered cheap and less aesthetically pleasing. Antibiotic treatment is expensive; therefore, less valuable palms may be perceived as not worth the cost of sampling, testing, and treatment. In contrast, systematic sampling at FLREC, where the disease is spreading naturally, showed that the amount of declining Sabal palmetto was comparable to the infection rates of Phoenix spp. observed in some nursery settings (B.W. Bahder, unpublished data). However, until a reliable vector assay is developed, it cannot be determined with certainty which palm species are more susceptible.

The epidemiological significance of the detection of the 16SrIV-D phytoplasma in Miami-Dade and Monroe Counties, where palm diversity is especially high, is unknown. It is unclear whether the phytoplasma has naturally spread to these areas, or if the samples represented palms that were infected in a different area with more disease pressure and were subsequently transported to the location where they were finally sampled. Regardless, these infections pose a huge risk to other susceptible palms in the extreme southern portion of the state. It is highly likely that more new host species will emerge in the coming years if 16SIV-D becomes established in this region of Florida. Before this study, the 16SrIV-D phytoplasma from 22 different counties in Florida was recorded (Harrison and Elliott 2016) (Fig. 7). With eight new counties emerging from this survey, this number is now 31 (Table 3) (Fig. 7). The samples received from stakeholders were mostly from urban areas and nurseries within those areas, and they represent only a small fraction of the total palms declining from the 16 SrIV-D phytoplasma. Although no formal assessment of the economic impact of the 16SrIV-D phytoplasma on the nursery and landscaping industry has been performed, it is likely that the loss incurred will be tens of millions of dollars, or potentially as high as hundreds of millions of dollars. In one instance, $100 \%$ crop loss because of $P$. sylvestris was documented, which amounted to a loss of $\$ 4.5$ million dollars reported by a single grower (anonymous grower, personal communication). As of 2010, for the nursery and landscape industries in Florida, palms have an approximate sales value of \$404 million (Khachatryan and Hodges 2017). Moreover, the recent initiatives by the Florida Department of Transportation to plant more palms along the major highways in Florida is likely to exacerbate losses caused by this disease. Based on the impact seen in a single nursery plot, as well as a preliminary assessment through samples received by stakeholders, it is apparent that $L B D$ is widespread in Florida and poses a significant threat to the sustainability of palm production there.

The findings of this survey are important from biological and applied standpoints. It demonstrated that this pathogen is actively spreading in time and space throughout the state as well as expanding into new palm hosts. Future efforts are required to survey declining palms in both urban environments and natural areas of Florida to obtain a clear understanding of the disease incidence and broader impact.

\section{Acknowledgments}

The authors thank the anonymous stakeholders for sample submissions.

\section{Literature Cited}

Bahder, B. W., and Helmick, E. E. 2018a. Lethal yellowing (LY) of palm. UF/ IFAS Extension document PP-222.

Bahder, B. W., and Helmick, E. E. 2018b. Sampling palms for lethal yellowing and Texas Phoenix palm decline phytoplasmas. UF/IFAS Extension document ENY-990.

Bahder, B. W., Helmick, E. E., Chakrabati, S., Osorio, S., Soto, N., Chouvenc, T., and Harrison, N. A. 2018. Disease progression of a lethal decline caused by the 16SrIV-D phytoplasma in Florida palms. Plant Pathol. 67:1821-1828.

Bahder, B. W., Helmick, E. E., and Harrison, N. A. 2017. Detecting and differentiating phytoplasmas belonging to subgroups 16SrIV-A and 16SrIV$\mathrm{D}$ associated with lethal declines of palms in Florida using qPCR and highresolution melt analysis (HRMA). Plant Dis. 101:1449-1454.

Bahder, B. W., Soto, N., Komondy, L., Mou, D., Humphries, A. R., and Helmick, E. E. 2019. Detection and quantification of the 16SrIV-D phytoplasma in leaf tissue of common ornamental palm species in Florida using qPCR and dPCR. Plant Dis. 103:1918-1922.

Corbett, M.K. 1959. Diseases of the coconut palm. Principes 3:5-12, 39.

Córdova, I., Oropeza, C., Puch-Hau, C., Harrison, N., Collí-Rodríguez, A., Narvaez, M., Nic-Matos, G., Reyes, C., and Sáenz, L. 2014. A real-time PCR assay for detection of coconut lethal yellowing phytoplasmas of group 16SrIV subgroups A, D, and E found in the Americas. J. Plant Pathol. 96: 343-352.

Dey, K. K., Jeyaprakash, A., Hansen, J., Jones, D., Smith, T., Davison, D., Srivastava, P., Bahder, B., Li, C., and Sun, X. 2018. First report of the 16SrIV-D phytoplasma associated with decline of a Bismarck Palm (Bismarckia nobilis). Plant Health Prog. 19:128.

Giesbrecht, M., Schuster, G., and Ong, K. 2014. Date palm lethal decline in Texas landscapes. Texas A\&M AgriLife Extension Document EPLP-012.

Harrison, N.A. and Elliott, M.L. 2016. Texas Phoenix Palm Decline. UF/IFAS Extension document PP243.

Harrison, N. A., Helmick, E. E., and Elliott, M. L. 2008. Lethal yellowing-type diseases of palms associated with phytoplasma newly identified in Florida, USA. Ann. Appl. Biol. 153:85-94.

Harrison, N. A., Helmick, E. E., and Elliott, M. L. 2009. First report of a phytoplasma-associated lethal decline of Sabal palmetto in Florida, USA. Plant Pathol. 58:792.

Harrison, N. A., Womack, M., and Carpio, M. L. 2002. Detection and characterization of a lethal Yellowing (16SrIV) group phytoplasma in Canary Island Date Palms affected by lethal decline in Texas. Plant Dis. 86:676-681.

Howard, F. W., and Collins, M. E. 1978. Palm species susceptible and resistant to mycoplasmalike organism-associated lethal declines in Fairchild tropical garden. FL-78-5, Agricultural Research Center - University of Florida. 
Jeyaprakash, A., Sutton, B. D., Halbert, S. E., and Schubert, T. S. 2011. First report of a 16SrIV-D phytoplasma associated with Texas Phoenix Palm Decline on Pigmy Date Palm (Phoenix roebelinii) in Florida. Plant Dis. 95:1475.

Khachatryan, H. and Hodges, A.W. 2017. Florida nursery crops and landscaping industry economic impacts, situation, and outlook. UF/IFAS EDIS document FE946.

Kumar, S., Stecher, G., and Tamura, K. 2016. MEGA7: Molecular Evolutionary Genetics Analysis version 7.0 for bigger datasets. Mol. Biol. Evol. 33: 1870-1874.

Lara, I. C., Narváez, L. M., Hau, C. P., Oropeza, C., and Sáenz, L. 2017. Detection and identification of lethal yellowing phytoplasma 16SrIV-A and D associated with Adonidia merrillii palms in Mexico. Australas. Plant Pathol. 46:389-396.
Narváez, M. I., Ortíz, E., Silverio, C., Santamaría, J. M., Espadas, F., and Oropeza, C. 2017. Changes observed in Pritchardia pacifica palms affected by a lethal yellowing-type disease in Mexico. Afr. J. Biotechnol. 16:2331-2340.

Rich, P. M. 1987. Developmental anatomy of the stem of Welfia georgii, Iriartea gigantea, and other arborescent palms: implications for mechanical support. Am. J. Bot. 74:792-802.

Singh, R. R., and Ferguson, M. H. 2017. First report of a 'Candidatus Phytoplasma palmae'-related subgroup 16SrIV-D phytoplasma on Trachycarpus fortunei. Australas. Plant Dis. Notes 12:59.

Vázquez-Euán, R., Harrison, N., Narvaez, M., and Oropeza, C. 2011. Occurrence of a 16SrIV group phytoplasma not previously associated with palm species in Yucatan, Mexico. Plant Dis. 95:256-262. 